\title{
Integrated environmental management of current reservoirs and regulated rivers
}

\author{
Antoni Palau
}

Dep. Medi Ambient i Ciències del Sòl. Universitat de Lleida. Av. A. Rovira Roure, 177. 25191-Lleida

(Spain).apalau@macs.udl.es

Dep. Medio Ambiente y Desarrollo. Endesa.apalau@enher.es

\begin{abstract}
At present, it is a common practice to identify reservoirs as the cause of negative effects on the regulated reaches of rivers. Reservoirs and regulated rivers maintain a close unidirectional relationship, downstream, so that the management of a reservoir, in addition to conditioning its own ecological characteristics, also determines the organization, operation and possibilities of the regulated river ecosystem.

Within Spain, the four main environmental problems affecting the reservoir-regulated river system are the alteration of flow regimes, the eutrophication, the interruption of sediment transport and the increasing practice of introducing exotic species.

It is possible to continue to draw an indefinite list of the concerns in measuring and criticizing the impacts of reservoirs on rivers, even proposing the demolition of dams, but it is also possible to think about the strategic value of reservoirs in guaranteeing availability of water and the preservation of the standards of living obtained as a result, and to therefore promote an environmental management program to reduce the negative impacts upon the rivers. The options for controlling levels and flows offered by almost any dam, together with the inclusion in the operating program of each reservoir of a set of environmental goals for the reservoir itself and for the downstream regulated river, is an area of application within limnology which has not been as propagated as it should have been. Many myths have still to be demolished -although perhaps no as many as there are dams proposed- and there is considerable margin for the improvement of regulated rivers. The environmental management options can not be tackled in one single paper, and therefore our aim here is to merely offer a series of basic reflections from which an environmental management approach of the reservoirs might be drawn up, and can be integrated with the uses for which they were built and with current social demands concerning the conservation of continental aquatic ecosystems.
\end{abstract}

Keywords: reservoir, regulated rivers, management, eutrophication, environmental flows, sediments, silting, exotic species.

\section{RESUMEN}

En la actualidad, es bastante común identificar los embalses como causantes de efectos negativos sobre los tramos de río regulados. Los embalses y los ríos regulados guardan una relación intensa y unidireccional, río abajo, de modo que la forma de gestionar el embalse, además de condicionar sus propias características ecológicas, determina también la organización, el funcionamiento y las posibilidades del ecosistema fluvial regulado.

En España, los cuatro principales problemas ambientales que afectan al sistema embalse-río regulado son la alteración del régimen de caudales, la eutrofización, la interrupción del transporte de sedimentos y la creciente introducción de especies exóticas. Se puede continuar indefinidamente con las preocupaciones en medir y criticar los impactos de los embalses sobre los rios, incluso se puede proponer la eliminación de presas, pero también se puede pensar en el valor estratégico de los embalses para garantizar la disponibilidad de agua y la preservación de los niveles de calidad de vida alcanzados gracias a ellos, y promover una gestión ambiental que reduzca sus impactos negativos sobre los ríos. Las opciones de manejo de niveles y caudales que ofrece prácticamente cualquier presa, junto con la inclusión dentro del programa de explotación de cada embalse, de unos objetivos ambientales para el mismo y para el tramo de río regulado río abajo, es un campo de aplicación de la limnología que no por conocido, se haya prodigado hasta donde sería deseable. Quedan muchos tópicos por demoler-aunque quizás no tantos como presas propuestas- y mucho margen para la mejora de los rios regulados. Las opciones de gestión ambiental son inabordables en un solo artículo, de modo que no se pretende más que exponer una serie de reflexiones básicas sobre las que poder elaborar un enfoque de gestión ambiental de los embalses, integrable con los usos para los que fueron construidos y con las demandas sociales actuales en materia de preservación de los ecosistemas acuáticos continentales.

Palabras clave: embalse, ríos regulados, gestión, eutrofización, caudales de mantenimiento, sedimentos, colmatación, especies exóticas. 


\section{INTRODUCTION}

Reservoirs and regulated rivers are two types of inseparable aquatic ecosystems, with a common origin and a unidirectional relationship. One does not exist without the other and both arise from the need to exploit water resources. Everything which takes place in the reservoir affects the regulated river downstream, but this is not so the other way around.

Currently, in developed countries, social perception -especially urban perception- more easily identifies the negative environmental impacts of reservoirs and is unaware or does not value the positive effects to the same extent.

For their part, regulated rivers, often subject to very low flow rates, are or normally appear to be incomplete or degraded fluvial ecosystems.

Given this panorama, there are many who blame the reservoirs for a large part of the harm suffered by the rivers, some calling for the demolition of dams for a variety of reasons (Poff \& Hart, 2002; Brufao, 2002), while others value the contribution of this type of artificial ecosystem to modern welfare which, whether or not it is recognized, is largely due to the control of the availability of water and energy, both in time and in space; that is, due to the presence of reservoirs and regulated rivers (Berga et al., 2002). Not in vain is $70 \%$ of the water demand from reservoirs in Spain applied to water consumption uses (Iversen et al., 2000).

Reservoirs and regulated rivers have significantly contributed to the scientific progress and social projection experienced by limnology in recent decades, facilitating moving from theories to solutions in the face of practical water management problems. Reservoirs and regulated rivers are excellent systems for experimenting with and validating almost any ecological paradigm (Ward \& Stanford, 1984; Straskraba et al., 1993).

It is certainly true that there are badly designed or unnecessarily built reservoirs, and there are definitely overexploited reaches of regulated rivers. It is possible to continue criticizing the situation, but it can also be viewed as an inherited situation which can and must be improved using environmental management principles in agreement with current limnological knowledge and based upon already available experience.

This paper offers a personal view of some of the main environmental problems associated with reservoirs and regulated rivers, and also sets out some personal considerations on the management of this type of ecosystem, focused on improving the ecological condition and its integration into the fluvial ecosystem to which it belongs.

\section{RESERVOIRS AND REGULATED RIVERS}

\section{Environmental key effects to manage}

From a limnological point of view, Margalef (1983) presents reservoirs as a hybrid between a river and a lake, indicating that their study must be based upon an overall vision of limnology. Indeed, at first approximation, the reservoirs as ecosystems have a section which operates as a river in the tail area and another which acts as a lake in the area around the dam (Kimmel et al., 1990); however they form a type of system with a personality of their own (Thornton et al., 1984; Thornton, 1990; Straskraba et al., 1993) because they have different characteristics of organization from those they would have if a river and a lake were directly linked together. In fact, among other considerations, it should be noted that the morphology of the basin is markedly asymmetric, the water renewal times are on the whole shorter than those of lakes, fluctuations in level are great and independent of the natural regime of the river, and the output of water downstream is almost always from the deepest part of the reservoir. With respect to regulated rivers, as their name indicates they present an organization adapted to an energy flow lower than in natural rivers, which in general leads to the establishment of equilibrium situations in which the river acquires its own characteristics different to the expected functional continuum gradient (Ward \& Stanford, 1984).

The negative environmental impacts of reservoirs are well known (Margalef, 1983, Hellawell, 1988; Gujja \& Hunziker, 2000). However, there 
are also positive environmental effects and some of those classified as negative, spread so widely, such as the barrier effect on species like the otter, do not appear to be verifiable on a population scale (Palau, 2002), and now there are even signs that the tail area of reservoirs may play a major positive role in otter conservation, at least in Mediterranean environments (Ruiz-Olmo et al., 2005).

There is a similar case for fishes in the middle and upper sections of rivers, for which the threats from segmentation and the isolation of populations as a result of the dams, in many cases, have little foundation in the view of the results of certain excellent works unfortunately unpublished (Sostoa et al., 1995).

Rightly, Poff \& Hart, (2002) stress the importance of having an ecological classification system for reservoirs in order to typify their effects on rivers. Table 1 shows the main negative and positive effects that usually appear in environmental impact studies on the construction of big dams and reservoirs. All these effects are the consequence of the change in organization experienced by the riverine ecosystem (increase of lacustrine conditions, river continuum interruption and flow regulation), in addition to the characteristics of the reservoir and its exploitation.

If one was to choose in the reservoirs already built within Spain, the aspects producing the most negative ecological consequences and which admit more management possibilities, these would probably be the control of the trophic condition of the reservoirs, the management of retained sediment and the application of a suitable environmental flow regime. One more point should be added to this list, socially accepted but ecologically serious, and this is the introduction of exotic species arising from the increasing recreational use of rivers in general and of reservoirs in particular. In fact, this last point is probably the most serious environmental and unsolvable problem in Spanish and Portuguese rivers and reservoirs.

\section{Environmental goals in reservoirs and regulated river management}

The environmental management of reservoirs and regulated rivers must be conceived from a global point of view and linked between these two types of aquatic systems, given that the objectives are, on the whole, common and complementary. These objectives are easy to list but difficult to reach fully given that, often when the technical and limnological aspects are overcome, social, economic, and even legal conditions remain requiring more complex solutions. Eutrophication, the appearance of which is more likely and more intense in reservoirs than in regulated rivers, conditions nevertheless their water quality. Controlling the level of nutrients reaching the reservoirs and maximizing their processing capacity in the reservoir-regulated river system, are therefore the two key objectives.

A similar thing occurs with sediment retention. The objective is also to avoid the silting up of the reservoir and to improve the transit and draining of sediment downstream, in the most natural manner.

In the light of the alteration of natural flow rate as a consequence of reservoir exploitation, given that flow regime plays a key role in the structure, organization and composition of the

Table 1. Main effects of the construction and presence of large dams and reservoirs. Principales efectos de la construcción y presencia de grandes presas y embalses.

\section{NEGATIVE EFFECTS}

Flooding of fertile lands

Population displacement

Barrier effect on fauna

Alteration of the landscape

Eutrophication

Alteration of the river's hydrological regime

Sediment retention

\section{POSITIVE EFFECTS}

Regulation of spillover

Supply to cities and industries

Irrigation

Production of hydroelectrical energy

Recreational use (introduction of exotic species) 
lotic aquatic ecosystems (Palau \& Alcazar, 1996; Richter et al., 1997), the objective is to obtain an environmental flow regime able to supply all the essential hydrological requirements of the regulated river downstream.

Finally, with respect to the introduction of exotic species, the objective is to eradicate these or, in the worst-case scenario, ensure a strict control of the populations.

The fact that reservoirs are bodies of water, artificially confined and controllable, implies many environmental management benefits in comparison with lakes. For instance, and in addition to being able to vary the residence times of dammed water and even select different depths (Toja, 1982), it is also possible to help the stirring up of sediment and control the supply of flow downstream, to the advantage of both the reservoir and the regulated reach of river.

\section{Managing reservoir eutrophication}

Eutrophication of reservoirs is a well-known cultural phenomenon regarding its causes and effects. As Margalef (1976) indicated, it is a problem linked to the activity of man, to which reservoirs are fatally condemned, in a greater or lesser degree, from the beginning.

The appearance of eutrophication in reservoirs is a consequence of how these ecosystems process, either retaining towards the sediment or expelling towards the atmosphere depending upon each case, phosphorus, carbon and nitro- gen, which frequently improves water quality downstream, in terms of balance of mass.

Predicting the susceptibility of each new reservoir to eutrophication, using one of the existing models (Ryding \& Rast, 1993) should be the first obligatory step for preparing the construction project and defining the management guidelines. In addition to the nutrient load (phosphorous) received by the reservoir, the rate of water renewal (Straskraba, 1999), the morphology of the reservoir basin, the management type and draining capacity, the location and nature of water outlets are essential for knowing what action to take in the control of reservoir eutrophication and its effects downstream, in addition to defining more suitable methods of management (Straskraba et al., 1993; Palau, 2003).

When preventing eutrophication, it is essential to limit the entrance of phosphorous to the reservoirs through appropriate urban, industrial, agricultural, forestry and hydrological management of the basin. This task is not easy given that an excess of phosphorous is mobilized in a significant proportion through diffuse sources with little or no available control. In addition, the majority of controlled effluents, after wastewater treatment, are not usually suited to phosphorous removal.

With respect to a new reservoir, the planning of the first years of filling may help to reduce the inevitable initial stage of eutrophication, in addition to the intensity of its lifelong effects. The prior removal of organic matter (vegetation, soil) from the new flooded zone is impor-
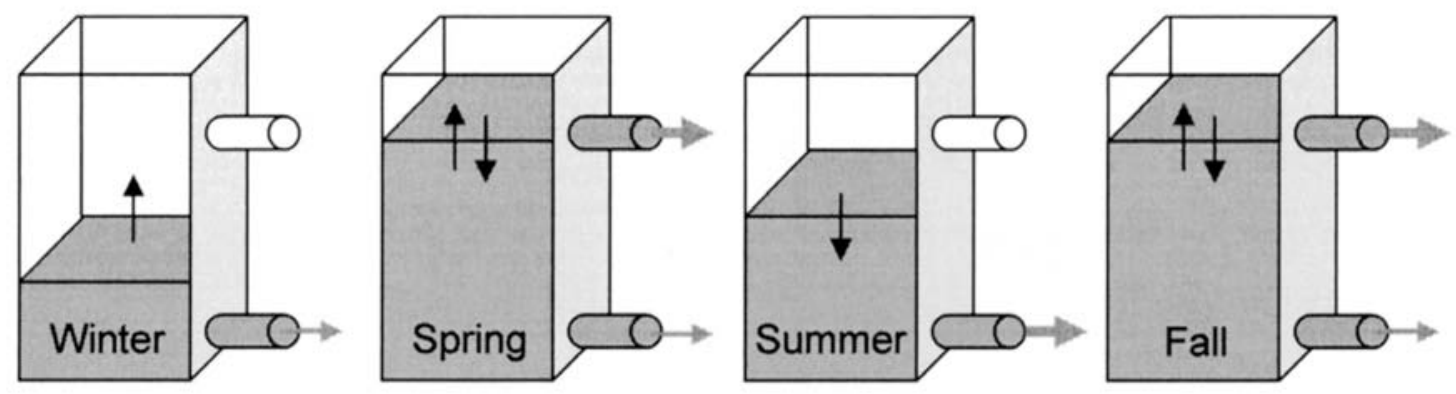

Figure 1. Plan proposal for the first filling of a reservoir, in order to reduce intensity and duration of the initial phase of eutrophication. Propuesta de plan para el primer llenado de un embalse, con el fin de reducir la intensidad y la duración de la fase inicial de eutrofia. 
tant. Similarly it is important to select the appropriate time of the year at which to make the first filling and the manner in which it is to be done (p.e duration, selective extraction of water at different depths). Figure 1 proposes winter as a good time for the first filling of a reservoir, with cold, dense and well-oxygenated incoming water, which could meet the oxygen requirements at the bottom of the recently flooded area. Use depth water discharges will favour the renewal of water in contact with sediment. In spring, the body of water has light, heat and nutrients (external and internal load). This is the time for controlling the algal biomass on the surface and encouraging the maximum drag possible of plankton downstream through surface water outlets. In this way the organic and nutrient load in the reservoir is reduced, as is the hypolimnetic oxygen requirement for the forthcoming summer. The regulated river, if the flow regime is correct, is easily able to process the plankton extracted from the reservoir thanks to its high capacity for aeration and transport. With the approach of summer, the circulation and renewal of the water at depth must again be favoured and the water level of reservoir, left at the minimum possible in order to prevent situations of anoxia and to allow sediment contact with the atmosphere (mineralization). The situation in spring is repeated in autumn, taking care to try to exploit the usual algal production peak in order to evacuate this downstream through the surface water outlets.

Seasonal management of an operational reservoir with problems of eutrophication may adopt guidelines similar to those proposed in figure 1, adapting them to the hydrodynamic behaviour of the reservoir in question, especially where the function of the reservoir is to supply water to populations and the dam is equipped with water outlets at different depths (Straskraba et al., 1993).

Downstream of the reservoir, methods of management with respect to eutrophication should basically be based on three objectives: to encourage good hydraulic characteristics for the mixture, transport, and aeration, to provide suitable physical habitat conditions, and to keep primary production controlled, in particular with respect to the development of macrophytes. These three objectives can be reached if sufficient hydraulic heterogeneity of the riverbed is maintained downstream of the reservoir and if a suitable flow regime is applied. This subject is discussed below.

Margalef (1983) showed a certain tendency to favour the biomanipulation or the introduction of planktivorous fish species in reservoirs (e. g. Coregonus, Tilapia, Alburnus), as a means to control eutrophication. The fact is that this type of action may even be counterproductive, benefiting the development of phytoplankton even more by encouraging a zooplankton of smaller size with a less efficient filtering capacity (Köthe et al., 1997; Sell et al., 1997); however, there are some positive experiences in small and eutrophic water bodies (Straskraba et al., 1993). In addition, the introduction of exotic species of fish in general, as described below, may have extremely negative collateral effects, including the appearance of other undesirable species (ciliates, molluscs, etc.) associated with the introduced fish.

In the case of massive developments of aquatic plants in the actual reservoirs (e. g. Eichornia, Lemna, Pistia, Egeria), as is not unusual in tropical reservoirs, control is complex and success limited. It requires management plans that include mechanical, biological and even chemical methods of control, (Tanaka et al., 2003). There are spectacular cases, such as the Muña reservoir (Colombia) that receives the wastewater from Bogotá. More than $80 \%$ of the surface of this reservoir is covered with Eichornia crassipes and the water column is pitch black and anoxic throughout the year. Bad odours, corrosion and mosquitoes are major problems for neighbouring populations, in addition to supposing considerable economic repercussions in corrective measures for the proprietary hydroelectrical company.

\section{Desilting reservoirs}

Eutrophication is an inherent process at the initial filling of any reservoir, and sediment retention is no less important.

The rivers not only transport water but in addition to particulate organic matter and dis- 
solved substances, they also carry particulate material of mineral origin, the dynamics of which are important from an ecological point of view, both at the point of origin (basins), and during transit as well as the point of stabilisation (riverbed, lakes, marshes, seas and oceans).

Generally, with ordinary flows part of the inert particulate material is carried in suspension, with a behaviour similar to that of a fluid, while the other minor part, moves close to the riverbed, following a pattern of displacement in pulses, with complex dynamics. The reservoirs modify the transport in suspension and practically eliminate bottom transport, thus experiencing a more or less intense process of silting up. Besides, the regulated riverbed suffers from processes of armouring, enlargement, and incision, more or less significant, with consequences for the entire biotic organisation of the fluvial ecosystem. A thorough review of reservoir silting up, its effects and possible corrective measures, can be found in Batuca \& Jordaan (2000).

Reservoir silting up, like eutrophication, is evident in both the reservoir itself and in the regulated section downstream and also admits preventive and corrective measures.

At a preventive level, the use of predictive models of the production and sediment type expected from the reservoir basin, allows the incorporation at project level of certain structural and significant design measures, as is the case with seals and abrasion-resistant materials, bypass systems for floods - which are always those carrying the maximum sediment loads- tail area reservoirs or changes in the height of the dams, in the level of the water outlets or in the capacity of the bottom outlets, among others (Palau, 2002).

For the de-silting of reservoirs, sediment distribution in the interior of the reservoir, together with their size and chemical characteristics, are essential points to consider when planning any action. One option is dredging, the efficiency of which has always been questioned; nevertheless some experiences with acceptable results can be seen even for deep reservoirs (Jacobsen, 2003). After extracting the sediment there is the problem of disposal. The ideal would probably be to gradually depo- sit it downstream, in combination with hydrological-forestry stabilisation actions at the source basin. Normally it is transported to dumping areas with a variety of possibilities, ranging from composting, to the recovery of degraded areas. In any case prior dehydration is usually required (drying, compression...) and sometimes chemical treatment is necessary, either for stabilisation (Murakami et al., 2004) or for agronomic reuse with the option to exploit the accumulated organic phosphorous.

Another option is to completely drain the reservoirs using the bottom outlets. In this way it is possible to remove a considerable volume of sediment downstream. In Spain, a number of large reservoirs have already been emptied and drained for different aims (Santa Ana, Barasona, Alloz, Doiras, Sallente, etc.), which have served to provide empirical data concerning the more significant aspects of this type of action. To date, the best-documented experience is undoubtedly the case of the Barasona reservoir (river Ésera, Huesca), where it was possible to analyse the considerable environmental impact of this type of action, both at the reservoir itself and in the downstream section of the river. A collection of the main monitoring work carried out during the draining of the Barasona Reservoir has been published in Limnetica (1998; vol. 14). It was possible to confirm that the effects of the action were totally reversible in the short to medium term and the positive end results for the aquatic system (reduction of the nutrient load and elimination of exotic fish species in the reservoir, recovery of amphibian populations, improvement of downstream river banks, etc.).

The best option in the prevention and correction of silting up in operational reservoirs, is once again, however, the management of stored water levels, periodic control of the outlets, depth water discharges of the dam and the application of regular floods. Consequently, the maintenance of low reservoir levels, together with the use of bottom outlets at times of natural floods, is the best way to mobilise sediment inside the reservoir towards the dam area in order to evacuate it downstream, as well as 
Table 2. Criteria established in different countries, for calculating environmental flows. Criterios establecidos en distintos países, para el cálculo de los caudales ambientales.

\begin{tabular}{ll}
\hline COUNTRY & MOST FREQUENT CRITERIA \\
\hline Spain & $10-20 \%$ of annual average flow. \\
France & $10 \%$ of annual average flow but for modules over $80 \mathrm{~m}^{3} / \mathrm{s}, 5 \%$ of the module is admissible. \\
Italy & $10 \%$ of the annual module in some regions and in others a specific flow rate of $21 / \mathrm{s} . \mathrm{km}{ }^{2}$ \\
(depending upon region) & $1-10 \%$ of annual average flow. \\
Ireland & $\mathrm{Q}_{347}$ (flow equal or greater $90 \%$ of the time throughout the year). \\
$\begin{array}{l}\text { Great Britain } \\
\text { (England and Scotland) }\end{array}$ & $\begin{array}{l}\text { The maintenance flow is deduced from an algorithm based on the Q } \\
\text { Switzerland }\end{array}$ \\
(La Vaudoise Canton Law) & as the "Mathey formula". \\
Austria & $\mathrm{Q}_{300}$ (flow equal or greater for 300 days of the year). \\
Germany & $30-60 \%$ of annual average flow. \\
United States & New England Flow Method (USFWS, 1981). Also known as the ABF (Aquatic Base Flow). \\
Canada (East coast) & $25 \%$ of annual average flow. \\
Republic of South Africa & Building Block Methodology (King et al., 2000). \\
\hline
\end{tabular}

maintaining the pipes and drainage systems of the reservoir clean and in working order.

The importance being attributed to reservoir silting up is resulting, in some countries such as Italy, in the development of recent specific legislation concerning reservoir silting up. In others countries, such as France, flood control criteria and complete ten-yearly reservoir drainage programmes have been applied for some years (Palau, 1998), significantly contributing to maintaining the continuous transport of sediment along the rivers.

Proposals currently exist for dredging reservoirs and depositing the sediment at the foot of the dam to allow the natural floodwater (or provoked from the reservoir) to distribute it downstream. This type of measure may reduce the degradation of the river bed as a result of the sediment retention in the reservoirs, and the local scouring around bridge piers, but it is difficult to sufficiently compensate for the deficit of sediment in order to conserve the great delta surfaces, as has been suggested for the case of the Ebro Delta, for example.

\section{Environmental flow rate for regulated rivers}

In spite of the progress experienced since the $80 \mathrm{~s}$ and reinforced in the $90 \mathrm{~s}$ in the develop- ment of methods for environmental flow calculation and testing of the consequences, the definition of environmental flows throughout the world follows common patterns. The number of regulated rivers with insufficient minimum flows continues to be a majority, calculating the rates using simple hydrological methods, the results of which do not exceed $10 \%$ of the annual average flow. Iversen et al., (2000) show how in Europe these criteria are applied to rivers from the Baltic to the Mediterranean (table 2). The same occurs in countries such as the United States (Reiser et al., 1989) or Canada.

In Spain, the regulations concerning environmental flows stem from the Basin Hydrological Plans (Ministry of the Environment) and the Fishery Laws (Autonomous Communities). The criteria for calculation vary, but are usually hydrological, based on a percentage of the annual average flow (table 3 ). The territorial differences between the hydrographic basins and the Autonomous Communities produce certain peculiar situations, where for the same river either the criteria of the relevant Hydrological Plan or the applicable fisheries legislation is adopted, resulting in very different environmental flows. 
The principal landmarks reached in defining environmental flows, all of which are interrelated, are possibly as follows:

- For the maintenance of a fluvial ecosystem, it is necessary to preserve not only the physical habitat but also the processes that regenerate and make that habitat more dynamic (a holistic approach according to Arthington, 1994).

- In-stream flow needs cannot be supplied with a constant flow. It is necessary to define complete environmental flow regimes (Palau, 1994).

- Each regulated river has specific requirements concerning environmental flows.

In most countries, the practical application of environmental flows in regulated rivers clashes with the water use rights awarded by the governments to individuals and businesses many decades ago under environmental criteria very different to those of today. In addition, it is a fact that in the great majority of the uses, water is put to play a relevant role whether from the point of view of energy, production or quality of life, especially in countries such as Spain, without energy reserves, with an industrial structure very dependent on the primary sectors and with irregular water distribution patterns in every way.

There are a number of ways to preserve regulated rivers, without severe infringement of water rights and all these have in common the agreements or compromise between the water users and public administration. The potential of these compromises is considerable, but, unfortunately, has yet to be explored.

Table 3. Criteria established in the different Hydrological Basin Plans and in certain Autonomous Communities, together with the denomination given to the environmental flows in each case. Criterios establecidos en los distintos Planes Hidrológicos de Cuenca y en algunas Comunidades Autónomas, junto con la denominación que en cada caso reciben los caudales ambientales.

\section{WATER AUTHORITY}

Norte I, II y III. Minimum flow

Duero

Tajo. Environmental demand Guadiana I y II. Minimum volume

Guadalquivir y Guadalete-Barbate

Environmental demand

Sur. Ecological flow

Ebro. Minimum flow

Júcar. Maximum stock

Segura. Minimum flow

Cuencas Internas de Cataluña.

Maintenance flow

Galicia-Costa. Minimum flow

\section{CRITERIA}

$10 \%$ of annual average flow, with $50 \mathrm{l} / \mathrm{s}$ as minimum.

Without specifications.

The volume corresponding to $50 \%$ of natural summer average flow.

$1 \%$ of natural incoming for each reservoir.

$50 \mathrm{l} / \mathrm{s}$ as maximum in addition to the admitted uses of water.

$10 \%$ of annual average flow.

$10 \%$ of annual average flow.

$1 \%$ of total water resources.

$10 \%$ of annual average flow.

QBM method (Palau \& Alcázar, 1996).

$10 \%$ of annual average flow.

\section{AUTONOMOUS COMMUNITY}

Galicia. Ecological flow

Asturias. Minimum ecological flow

Navarra. Minimum flow

Aragón. Ecological flow

Cataluña.

Maintenance flow

Castilla y León. Ecological flow

Castilla-La Mancha.

Minimum ecological flow

Extremadura. Minimum flow

\section{CRITERIA}

Any well verified method.

$20 \%$ of the annual average flow.

$10 \%$ of the annual average flow for "cyprinid rivers" and $\mathrm{Q}_{330}$ for

"salmonid rivers".

Without specifications.

QBM method.

$20 \%$ of the annual average flow.

$10 \%$ of the annual average flow.

Without specifications. 
At present, it is advisable to distinguish various concepts within the broad term of environmental flows. On the one hand are the minimal flows, which are the majority of those stemming from the legal framework (Hydrological Plans, Laws of Fisheries). These are flows which allow the conservation of river life only. They are established from arbitrary criteria, without ecological foundation.

Another type of environmental flow is what can be called "fitting out flows". In this case, these are flows defined for a set purpose other than the conservation of the fluvial ecosystem. This is the case of flows for the practice of rafting, recreational fishing, the landscape conservation, etc. They are calculated as those that enable the hydraulic conditions necessary to meet the desired goal.

Finally, there are maintenance flows (inappropriately named "ecological flows" in Spain), which are calculated to conserve the fluvial ecosystem. These are flows whose definition responds to scientific criteria.

By way of reference, minimum flows may be of the order of $5-10 \%$ of the average annual flow; adjustment flows are variable as they may be higher than natural flows at a specific time of year, while maintenance flows do not usually fall below $20 \%$ of the average annual flow.

There are many options for calculating environmental flows, which can generally be classified according to the data used or the conservation goals sought (Palau, 2003). Some methods are better than others and the criteria for identifying them should be based on the following aspects:

- Ecological grounds. The method should be supported by a solid ecological foundation.

- Objectivity. The process of calculation should not be arbitrary nor have decision-making points dependent upon who is applying the process.

- Universal applicability. The method should be applicable to any river, but with the capacity to distinguish between each river type.

- Focus on the ecosystem. The priority goal is to conserve the fluvial ecosystem and not the more supposedly sensitive species or aspects of indicator or representative value.
- Operability. The calculation process should be quick and, in as much as possible, inexpensive.

- Validation protocol. It should be possible to contrast the results on the basis of a validation protocol included in the actual calculation process.

Nowadays, when determining maintenance flows, hydrological methods of a statistical type are being used less frequently (p.e. percentages, flow duration curves). The hydraulic methods are also limited to specific applications. The hydraulic simulation models used in the characterisation of the physical habitat (hydrobiological methods) are improving and evolving towards two-dimensional approaches (mesohabitat). Sequential hydrological methods (Palau, 1994; Ritchter et al., 1997; Palau et al., 2002) and holistic methods (Arthington, 1994; King et al., 2000), based on an ecosystem approach and on the principle that each river has its own different requirements, have still much to offer.

The reasoning behind the sequential hydrological methods is simple: The series of circulating flows act as the rivers' genetic code as they contain key information for explaining the physical characteristics and the spatial and temporal organisation of the fluvial ecosystem (Palau \& Alcázar, 1996). This is what is known as the paradigm of natural flows and the integrity of aquatic ecosystems, (Ritchter et al., 1997).

The information contained in the series of circulating flows may be studied using time series trend analysis techniques that permit the detection of changes or discontinuities (Figure 2).

Figure 3 shows the points that, at minimum, every environmental flow regime should consider. The fundamental point is the Basic Flow $(\mathrm{Qb})$; this is the flow that should go downstream from the point of regulation or intake, as long as the natural flow is equal to or greater than this. Taking the Natural Flow (Qn) as a reference point, a Maintenance Flow (Qm) must be established. This is the Basic Flow modulated in time to the scale considered to be most appropriate (weeks, months, quarters). It should be noted that the correct application of the concept of time variability in a Mediterranean river may imply leaving it dry 

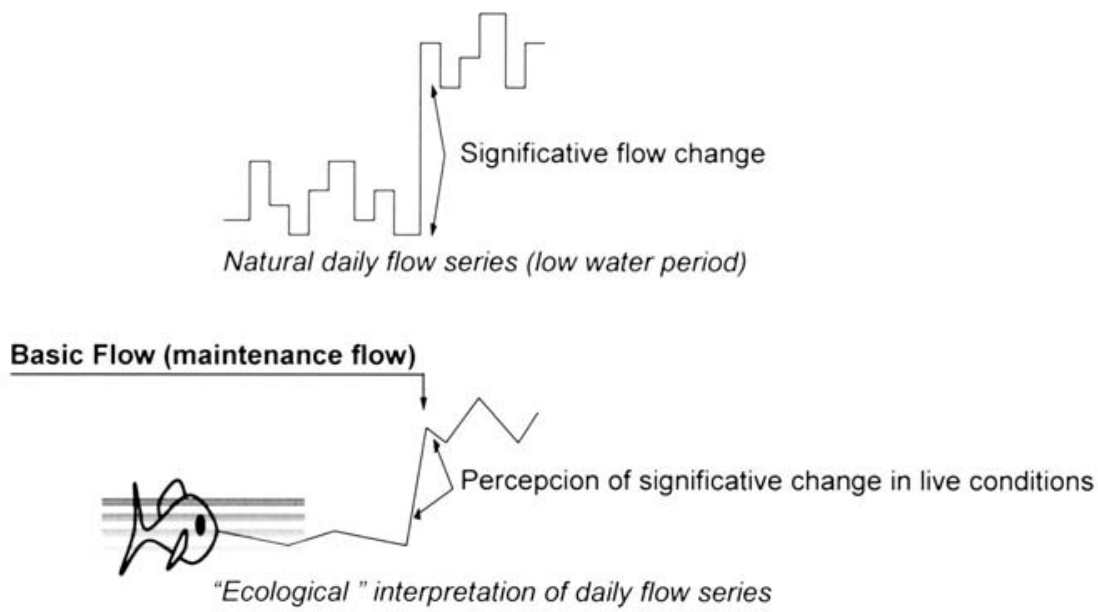

Figure 2. The application of moving averages at increasing intervals of data, within the natural daily flow series, allows for the "reading" of temporary information in a similar way to that which, in principle, the natural communities should; that is, integrating (accumulating) the information (each new variable flow) and responding to the discontinuities of that information (significant flow changes), which can be interpreted as indicators of change in the environment. On a hypothetical natural series of natural flows during the low water period, the Basic Flow could be a good approximation to the maintenance flow. La aplicación de medias móviles a intervalos crecientes de datos, dentro de las series de caudales circulantes, permite "leer" la información temporal de una forma muy parecida al modo en que, en principio, lo deben hacer las comunidades naturales; es decir, integrando (acumulando) la información (caudales circulantes) y respondiendo a las discontinuidades de dicha información (variaciones significativas) que puedan ser interpretadas como indicadoras de cambios en el medio. Sobre una hipotética serie de caudales naturales en el periodo de mínimos, el Caudal Básico podría ser el Caudal de Mantenimiento.

when appropriate, as would occur naturally at some point in the year.

Coinciding with the most likely time for floods, according to the natural regime of the river, Flushing Flows (Qf) should be established, the function of which is essential for the conservation of the fluvial ecosystem at many levels. A

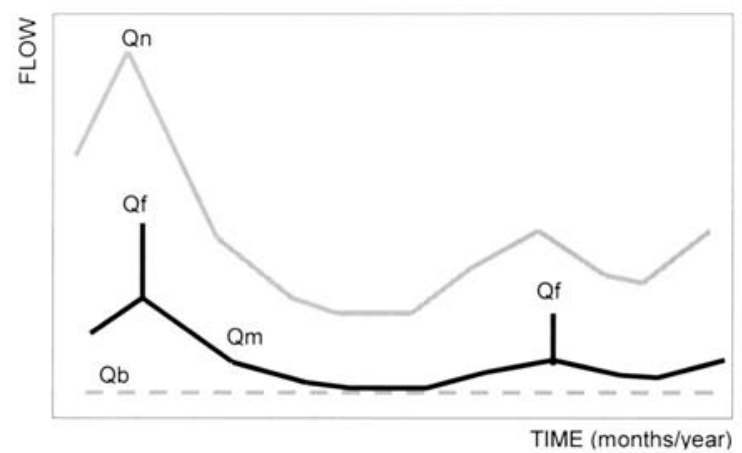

Figure 3. Essential hydrological components of any regime of environmental flows that aims to be functional. These aspects are not the only ones, but they are the most important. Componentes hidrológicos esenciales de cualquier régimen de caudales ambientales que pretende ser funcional. Estos aspectos no son los únicos, pero sí los más importantes. number of criteria exist for defining the flushing flows (Gore \& Petts, 1989) ranging from taking percentages of the average annual flow (p. e. $200 \% \ldots$, flows from a particular return period (p. e. 1.5 years, 2.3 years) or flows necessary to move a certain size of particle (p. e. from 1.3 to $3.8 \mathrm{~cm}$ ); some of these criteria include indications as to the most suitable time of year or duration for the flushing flows.

The floods fulfil a fundamental role in the management of regulated rivers (Brookes, 1995), especially in Mediterranean rivers where they are the only disruption able to introduce sufficient energy into an ecosystem to enable the necessary renewal, and to avoid the lack of ecological balances. Consequently, the application of regular controlled floods at set times favours the transport of solids, avoids excessive proliferation of primary producers, especially macrophytes (Palau et al., 2004), cleanses the riverbed, renews benthic communities, and maintains the river bank vegetation in good condition, which also helps benefit the section of regulated river (Pusey \& Arthington, 2003). 


\section{Control of exotic species}

With respect to the introduction of exotic species in 2001, the FAO database lists 3141 cases (Khalanski, 2001), the majority being fish (82\%), followed by molluscs (9\%) and crustaceans $(6 \%)$. Seven hundred and eighty nine cases were located in Europe, while in North America there were 198.

The fact that a great number of the exotic species introduced were fishes, molluscs or crustaceans $(97 \%$ of all the cases listed by the FAO) seems to indicate that these introductions are related to the practice of fishing in continental waters, navigation or aquariums. This should serve to make the Water Authorities take more action in controlling this type of activity, as the consequences for the fluvial ecosystem are often serious and somewhat irreversible (Granado, 2000), from the extinction of native species (including endemisms), genetic degeneration (where hybridisation is possible), and the appearance of new pathologies, among others.

In 1994, more than 20 exotic species of fish were known to exist in Spain (Granado, 1996; Elvira, 1997). Now the list may easily reach up to around 30, representing a higher number than that of native species, if estuary and salt-water environments are excluded.

From a hydrographical point of view, Spain and Portugal do not have huge bodies of natural water, or rivers with a sufficiently large and stable flow to have enabled the evolutionary consolidation of large and varied trophic networks (Granado, 1996). However the presence of more than 1200 large dams, mostly built after the mid twentieth century, has brought about the appearance of aquatic environments, reservoirs, particularly suited to the introduction of lenitic fish species. Indeed, reservoirs have become "new" biotopes for the native species, which are able to inhabit the reservoirs but not to efficiently exploit them. In contrast, they provide environments very well suited for predatory limnophila species. This simple fact, together with the complex economic framework surrounding recreational fishing, more than explains the profusion of exotic fish species in Spanish reservoirs.
A serious and recent effect associated with the illegal introduction of exotic fish species or rather with the uncontrolled practice of recreational fishing is the introduction of the zebra mussel (Dreissena polymorpha). First listed in the lower section of the Ebro (Ruíz-Altaba et al., 2001), it is currently established in the two large reservoirs at the end of this river (Riba-roja and Mequinenza) and is listed in the Sitjart reservoir (Valencia), in what can now be seen as an unstoppable geographical expansion. The effects of the zebra mussel on the fluvial ecosystem of the Ebro River are gradual but also irreversible (Palau et al., 2003). As a result of the filtering activity of that species, the composition and density of the plankton will change, and the covering of the riverbed will simplify the benthic community. The trophic network will therefore be affected at primary and secondary levels, and the absence of efficient predatory options on the zebra mussel will, at the same time, lead to an impoverishment in the higher trophic levels. The nutrient cycle and the production/respiration balance will also be affected, leading to conditions of substrate fertilisation on the one hand and to changes in the availability of oxygen dissolved in the riverbed on the other. The presence of certain ciliates and nematodes previously unlisted in Spain has already been detected, associated to zebra mussel populations of the Ebro River (Peribañez, 2004). One should not dismiss either the presence of new pathogens and diseases which may have entered with the zebra mussel and which will eventually affect the survival of certain species with a high conservation value such as Margaritifera auricularia.

On an economic level, the impacts of the zebra mussel are already considerable (obstruction of all types of water intakes as irrigation, urban supplies, industries, etc.), with major losses in efficiency, interruption to services, and increased maintenance costs. Recreational activities (swimming, fishing, etc.) are also to be seriously limited.

Once again, the adoption of an environmental flow regime which adjusts to the natural hydrogram, combined with management of the reservoir levels, can be assumed to be one of the only options available for controlling the develop- 
ment of the zebra mussel in natural environments, together with greater surveillance on the illegal introduction of species.

\section{CONCLUSIONS}

From the arguments presented above, it can be deduced that an appropriate programming of the management of reservoir levels and the flows in regulated river reaches, is the way to simultaneously confront the control of eutrophication, the continuity of longitudinal sediment transport, the conservation of the regulated river section and the prevention or limiting of the presence of exotic species. Consequently, controlled flooding from a reservoir through the bottom outlets, at a set time in the annual cycle, may prevent a deficit of dissolved oxygen in the hypolimnion. This permits a certain amount of evacuation and transport of sediment downstream, preventing losses in the quality of downstream water, regenerating the section of regulated river geomorphologically, cleansing and conditioning the riverbed, controlling the colonisation pressure of the river banks on the riverbed, controlling primary producers in the regulated section (macrophytes), and reducing the presence of exotic species, whether pelagic or sessile. The ecological effects of this type of management are therefore fundamental to the conservation of reservoirs and regulated rivers within acceptable levels of naturalisation.

Operating plans for optimising the hydraulic exploitation within the reservoir along with the incorporation of integrated environmental management criteria, does not necessarily imply a considerable additional cost, especially if the benefits to the fluvial ecosystem are internalised. At the end of the day, environmental management is a question of priorities, and its application will greatly depend upon how much society is prepared to prioritise, both at a social and an economic level (figure 4). By default, the objectives for the environmental management of reservoirs and regulated rivers might be defined as follows:
- To maintain the quality of stored water.

- To allow the passage of sediments.

- To have an environmental flow regime downstream of the dam.

- To accept recreational activities that present no risk to the biotic integrity of the fluvial ecosystem.

Nevertheless, in a country such as Spain, where a large proportion of the run-off water is committed to water permits for irrigation, hydroelectric production and supply, the environmental management of reservoirs and regulated rivers cannot be carried out by a public administration in favour of the continual generation of new taxes for water use. -Furthermore, this does not have a clear environmental reversal- nor by businesses locked in their rights to water usage; nor through scientific paradigms, often unrealistic. Not certainly by a society which repeatedly demands that the water run along the rivers, or even that the dams be removed, but which is unable to adopt the minimum measures to save water and energy. A meeting point more or less equidistant from all these positions is required. This is the common sense option, any other approach leads, as numerous experiences have demonstrated to this effect, to no-go positions where the only way out is through courts of law, whose decision may be long-winded, arbitrary and will always leave one party unsatisfied; meanwhile the rivers are waiting.

At present, it would seem reasonable to suggest that it is not a question of limiting the construction of new reservoirs, nor of calling for the demolition of existing reservoirs. The construction of reservoirs is no longer decided without considering the environmental impacts. Moreover, the decision to demolish dams, in a Mediterranean country such as Spain, with an obvious energy deficit, a highly irregular pattern of rainfall, a huge demand for water, and with a horizon of climate change towards aridity, perhaps should be left to the future. Meanwhile, between unjustified construction and indiscriminate demolition, a huge margin exists for managing the existing reservoirs in an environmentally improved manner. 


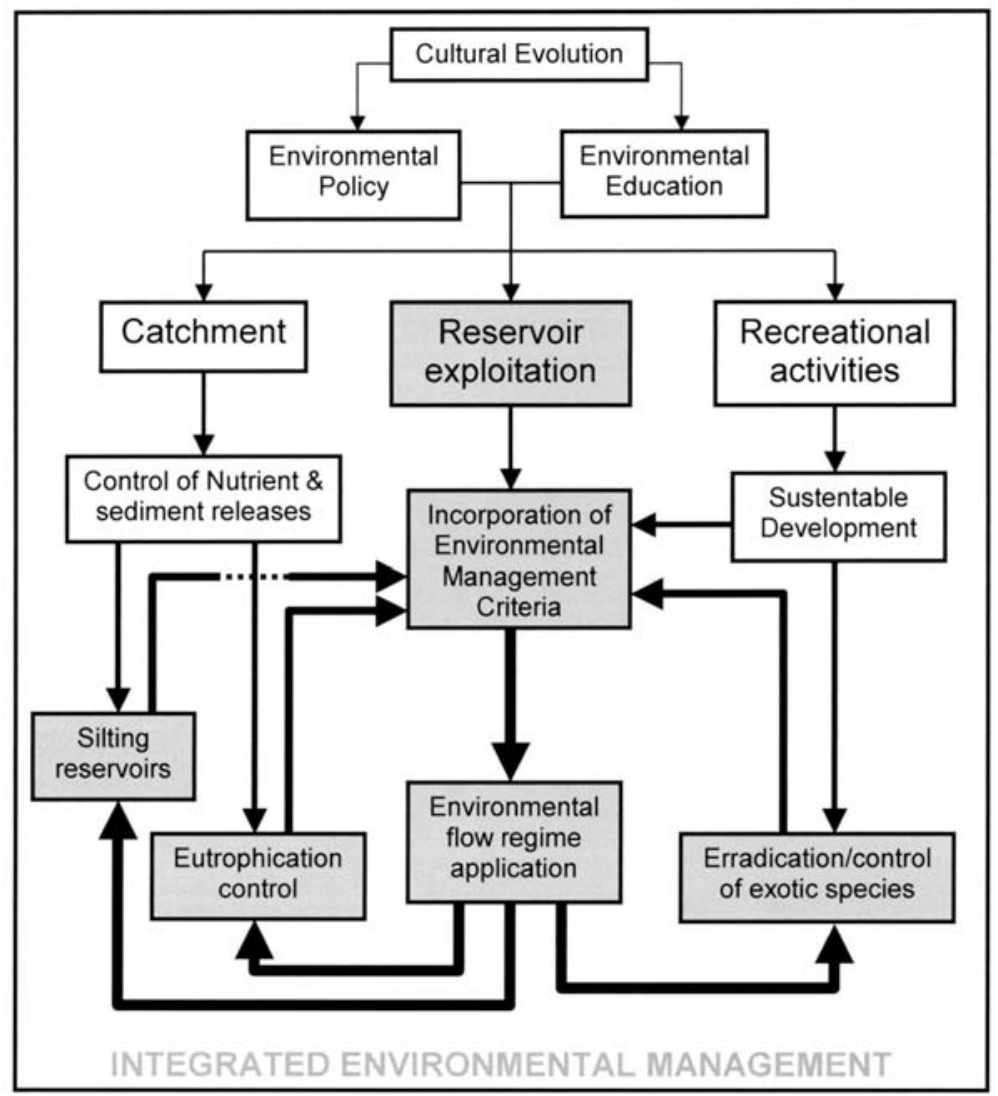

Figure 4. The cultural evolution of society, partly through need, but also from business, leads towards a growing degree of environmental awareness, which is gradually being included in new laws and regulations and should also reinforce itself in society, more than it currently does, through environmental education programmes. For the continental aquatic ecosystems, environmental action must be focused at the basin level (control of nutrients and erosion) in the reservoir exploitation plans (integrating environmental management criteria) and in the practice of recreational activities (promoting truly sustainable uses of the aquatic environment). La evolución cultural de la sociedad, en parte por necesidad pero también por negocio, conduce hacia un grado creciente de sensibilización ambiental, que se recoge de forma progresiva en nuevas leyes y reglamentos y que debería también consolidarse en la propia sociedad, más de lo que ahora lo hace, a través de programas de educación ambiental. Para las ecosistemas acuáticos continentales, las actuaciones ambientales han de focalizarse a nivel de cuenca (control de nutrientes y de la erosión), en los planes de explotación de embalses (integrando en ellos criterios ambientales de gestión) y en la práctica de actividades recreativas (promoviendo unos usos realmente sostenibles del medio acuático).

\section{ACKNOWLEDGEMENTS}

I will never be able to thank Dr. Ramon Margalef enough, for everything he put before me in order to learn from him, going beyond his science; he himself was probably unaware that he was teaching many of the points and of all of them one in particular: "look at any problem from all possible points of view, before proposing a solution and remember that this will never be the only solution". This is a very simple piece of advice, but is widely applicable in life.

\section{REFERENCES}

ARTHINGTON, A. H. 1994. A holistic approach to water allocation to maintain the environmental values of Australian streams and rivers: A case history. Mitt. Internat. Verein. Limnol., 24: 165-177.

BERGA, L. F. GIRÓN, J. CAJETE \& J M. MENDILUCE. 2002. Beneficios de las presas en España. Actas de las VII Jornadas Españolas de Presas. Comité Nacional Español de Grandes Presas. Zaragoza. Vol. IV: 3-15.

BROOKES, A. 1995. The Importance of High Flows for Riverine Environments. In: The Ecological 
Basis for River Management. D. M. Harper \& A. J. D. Ferguson (eds.).: 33-49. John Wiley \& Sons Ltd. BRUFAO, P. 2002. Desmantelamiento de obras hidáulicas: una innovadora e indispensable herramienta para la restauración. Actas de las VII Jornadas Españolas de Presas. Comité Nacional Español de Grandes Presas. Zaragoza. Vol. IV: 349-355.

ELVIRA, B. 1997. Impacto y control de los peces exóticos introducidos en España. In: Conservación, Recuperación y Gestión de la Ictiofauna Continental Ibérica. C. Granado (ed.).: 139-152. Publicaciones de la Estación de Ecología Acuática. EMASESA

GUJJA, B. \& D. O. HUNZIKER. 2000. The Impact of Dams on Life in Rivers. WWF Research Report. WWF International. Gland, Switzerland. 33 pp.

GORE, J. A. \& G. E. PETTS. 1989. Alternatives in regulated river management. CRC Press, INC., Boca Ratón (Florida; USA). 343 pp.

GRANADO, C. 1996. Ecología de peces. Secretariado de Publicaciones. Universidad de Sevilla. Sevilla. $353 \mathrm{pp}$

GRANADO, C. 2000. Ecología de las comunidades. El paradigma de los peces de agua dulce. Secretariado de Publicaciones. Universidad de Sevilla. Sevilla. $282 \mathrm{pp}$

HELLAWELL, J. M. 1988. River regulation and nature conservation. Regulated Rivers: Res. and Manag., 2: 425-443.

IVERSEN, T. M., B. L. MADSEN \& J. BOGESTRAND. 2000. River conservation in the European Community, including Scandinavia. In: Global Perspectives on River Conservation: Science, Policy and Practice. P. J. Boon, B. R. Davies \& G. E. Petts (eds.).: 79-103. John Wiley \& Sons Ltd.

JACOBSEN, T. 2003. Sediment handling technologies: experience from case studies. Hydropower \& Dams, 6: 84-87.

KHALANSKI, M. 2001. Introduction d'espèces invasives dans les hydrosystèmes: pestes et biosalissures. Actas del Colloque d'Hydroécologie d'Electricité de France. Chinon (France). 24 p.

KIMMEL, B. L., O. T. LIND \& L. J. PAULSON. 1990. Reservoir Primary Production. In: Reservoir Limnology. K. W. Thornton, B. L. Kimmel \& F. E. Payne (eds.).: 133-194. John Wiley \& Sons Ltd.

KING, J. M., R. E. THARME \& M. S. DE VILLIERS. 2000. Environmental Flow Assessments for Rivers: Manual for the Building Block methodology. Freshwater Research Unit.
University of Cape Town. WRC Report No: TT131/00. $339 \mathrm{pp}$

KÖTHE, A., V. FALTIN, N. KAMJUNKE \& J. BENNDORF. 1997. The structure-forming impact of zooplankton on phytoplankton in a whole-lake biomanipulation experiment. Verh. Internat. Verein. Limnol., 26: 712-714.

MARGALEF, R. 1976. Biología de los embalses. Investigación y Ciencia, 1: 51-62.

MARGALEF, R. 1983. Limnología. Ed. Omega. Barcelona. $1010 \mathrm{pp}$

MURAKAMI, A., MR. OZEKI \& Y. ISHIGURO. 2004. Sediment Dredging: Unplugging Ikawa Dam's Bottom Outlets. Hydro Review Worldwide, September 2004: 26-29.

PALAU, A. 1994. Los mal llamados caudales "ecológicos". Bases para una propuesta de cálculo. $O P$ (Obras Públicas), 28 (Ríos II): 84-95.

PALAU, A. 1998. El vaciado de embalses: Consideraciones ecológicas y gestión medioambiental. Ecología, 12: 79-92.

PALAU, A. 2002. Algunas cosas buenas de los embalses. Actas de las VII Jornadas Españolas de Presas. Comité Nacional Español de Grandes Presas. Zaragoza. Vol. IV: 217-227.

PALAU, A. 2002. La sedimentación en embalses. Medidas preventivas y correctoras. Actas del I Congreso de Ingeniería Civil, Territorio y Medio Ambiente, 1: 847-856.

PALAU, A. 2003. Medidas de gestión y adecuación ambiental de embalses frente a la eutrofia. Limnetica, 22 (1-2): 1-13.

PALAU, A. 2003. Régimen Ambiental de Caudales. Curso sobre Régimen Ambiental de Caudales. Universidad Internacional Menéndez Pelayo. Documento Inédito. Cuenca. 5 pp.

PALAU, A., \& J. ALCAZAR. 1996. The Basic Flow. An alternative approach to calculate minimum environmental instream flows. Proceedings of $2^{\text {nd }}$ International Symposium on Habitat Hydraulics. Quebec (Canada). Vol., A: 547-558.

PALAU, A., R. SÁNCHEZ, R. ROCASPANA, M. BARDINA \& I. REBOLLO. 2002. Validación del Caudal Básico según el método QBM en el cálculo de caudales mínimos ambientales. In: Validación hidrobiológica del método del Caudal Básico de Mantenimiento en el cálculo de caudales con fines ambientales. Informe Técnico. CEDEX clave 50499-6-002. Madrid. Vol. 1. 193 pp.

PALAU, A., R. J. BATALLA, E. ROSICO, A. MESEGUER \& D. VERICAT. 2004. Management of water level and design of flushing floods for envi- 
ronmental river maintenance downstream of the Riba-roja Reservoir (Lower Ebro River, NE Spain). Proceedings of HYDRO 2004. Porto (Portugal). S. 9.07.

PERIBAÑEZ, M.A. 2004. Estudio parasitológico del mejillón cebra en el tramo inferior del Ebro. Proyecto MZ. Documento Inédito. Endesa. Lleida.

POFF, N. L. \& D. D. HART. 2002. How Dams Vary and Why It Matters for the Emerging Science of Dam Removal. Bioscience, 52(8): 659-668.

PUSEY, B. J. \& A. H. ARTHINGTON. 2003. Importance of the riparian zone to the conservation and management of freshwater fish: a review. Marine and Freshwater Research, 54: 1-16.

RITCHTER, B. D., J. V. BAUMGARTNER, R. WIGINTON \& D. P. BRAUN. 1996. How much water does a river need? Freshwat. Biol., 37: 231249.

REISER, D. W., T. A. WESCHE \& C. ESTES. 1989. Status of instream flow legislations and practices in North America. Fisheries, 14(2): 22-29.

RUÍZ-ALTABA, C., P. J. JIMÉNEZ \& M. A. LÓPEZ. 2001. El temido mejillón cebra empieza a invadir los ríos españoles desde el curso bajo del río Ebro. Quercus, 188: 50-51.

RUÍZ-OLMO, J., A. MARGALIDA \& A. BATET. 2005. Use of small rich patches by Eurasian otter (Lutra lutra L.) females and cubs during the predispersal period. J. Zool. Lond., 265: 339-346.

RYDING, S. O. \& W. RAST. 1993. Le contrôle de l'eutrophisation des lacs et des reservoirs. Ed. Masson. UNESCO. Paris. 294 pp.

SELL, A. F., U. HORNING \& J. BENNDORF. 1997. Long-term effects of planktivore removal: results from a manipulated and a reference lake. Verh. Internat. Verein. Limnol., 26: 782-785.

SOSTOA, A. F. CASALS, E. APARICIO, M. J. VARGAS \& J. M. OLMO. 1995. Caudales Ecológicos.
Proyecto PIE 121.43. Documento inédito. OCIDE. Madrid. Vol.2 (III): 270-470.

STRASKRABA, M. 1999. Retention Time as a Key Variable of Reservoir Limnology. In: Theoretical Reservoir Ecology and its Applications. M. Straskraba \& J. G. Tundisi (eds.).: 385-410. International Institute of Ecology, Brazilian Academy of Sciences and Backhuys Publishers.

STRASKRABA, M., J. G. TUNDISI \& A. DUNCAN. 1993. State-of-the-art of reservoir limnology and water quality management. In: Comparative Reservoir Limnology and Water Quality Management. M. Straskraba, J. G. Tundisi \& A. Duncan (eds.). : 213-288. Kluwer Academic Publishers. Netherland.

TANAKA, R. H., A. L. MUSTAFA \& H. KURATANI. 2003. Managing Aquatic Plants in Reservoirs: Developing an Integrated Plan. Hydro Review Worldwide, Sep. 2004: 20-23.

THORNTON K. W. 1990. Perspectives on Reservoir Limnology. In: Reservoir Limnology. K. W. Thornton, B. L. Kimmel \& F. E. Payne (eds.).: 113. John Wiley \& Sons Ltd.

THORNTON, K. W., R. H. KENNEDY, A. D. MAGOUN \& G. E. SAUL. 1982. Reservoir water quality sampling design. Water Resour. Bull., 18 : 261-265.

TOJA, J. 1982. Control de la eutrofia en embalses por utilización selectiva de agua a distintas profundidades. Revista de Obras Públicas, AbrilMayo: 223-231.

USFWS. 1981. Interim regional policy for New England stream flow recommendations. US Fish y Wildlife Service. Newton Corner. Massachussets. 3 pp.

WARD, J. V. \& J.A. STANFORD. 1984. The regulated stream as testing ground for ecological theory. In: Regulated Rivers. A. Lillehamer \& S.J. Salveit (eds.).: 139-165. Oslo University Press. 